\title{
Religião Popular no Egito Greco-Romano: O Culto de SeráPIS
}

Danillo Melo da Fonseca ${ }^{1}$

\section{RESUMO}

Serápis foi um deus criado por Ptolomeu I Sóter, primeiro faraó da dinastia lágida (305-30 a.C.), como o deus guardião dos novos soberanos e da cidade de Alexandria. A representação iconográfica de Serápis seguia os moldes das divindades gregas, mas também é resultado de um elemento propriamente egípcio no nome. Com base na cultura material produzida em terracota, proveniente do Egito greco-romano e a qual representou Serápis, pretendemos analisar as práticas religiosas e a religião popular associadas ao deus. Partimos da hipótese de que Serápis é resultado do contato e emaranhamento das religiões egípcia e grega, fruto de um ambiente marcado pela miscigenação e por um estreito contato cultural.

\section{PALAVRAS-CHAVE}

Egito greco-romano; emaranhamento cultural; religião popular; Serápis; terracota.

\footnotetext{
${ }^{1}$ Graduando em História (Licenciatura) e bolsista de Iniciação Científica pela Universidade Federal do Rio Grande do Norte, Natal, Brasil. A realização desta pesquisa só foi possível graças ao apoio do CNPq. Email: danillo97melo@hotmail.com.
} 


\section{Introdução}

O presente estudo tem por objetivo investigar o aspecto popular do culto de Serápis no Egito greco-romano. Para tal, tomamos como fonte documental peças de terracota ligadas a Serápis produzidas no Egito no período ptolomaico e imperial romano. A terracota foi escolhida por permitir a pesquisa daquilo que denominamos religião popular, caracterizada por seu aspecto privado e presente entre as camadas menos favorecidas do Egito no período.

Este estudo se defronta com impasses que puderem ser testemunhados do começo ao fim da pesquisa, tais como a proveniência do material, no que se refere ao local/região em que foi encontrada, uma vez que $50 \%$ das peças não trazem essa informação, e a completa ausência de contato com o contexto arqueológico, o que impossibilita algumas afirmações mais detalhadas.

O primeiro problema que analisamos refere-se à progressiva transição de um culto oficial, unido à legitimação da dinastia ptolomaica, para um de caráter mais popular. Tal culto adentrou as residências de uma parcela da população não ligada diretamente ao poder estatal e nelas exerceu a função de divindade associada à cura de doenças, bem como de propiciadora de benesses e da fertilidade. Também é relevante o seu papel como deus ctônico guardião da vida após a morte e, ao mesmo tempo, vinculado a aspectos solares.

Outro problema é a análise da cultura material dentro de um contexto no qual se observa intercâmbios intensos entre aspectos culturais e religiosos. Por meio da elaboração de um corpus documental aos moldes de um catálogo arqueológico, visamos submeter tais peças à análise comparativa. Foram selecionadas todas as peças contidas nos livros Religion Populaire en Égypte Romaine (1979) e Catalogue des Terres Cuites Gréco-romaines d'Égypte (1990), ambos de autoria de Françoise Dunand, e pertencentes à coleção online de acesso público do Museu Britânico² ${ }^{2}$ o que nos proporcionou um corpus de total de quarenta e duas peças.

Para discutirmos a pluralidade de atributos greco-egípcios na constituição de Serápis, julgamos adequada a utilização do conceito de "emaranhamento material", do arqueólogo Phillip Stockhammer (2012). Para discurtirmos a pluralidade de atributos greco-egípcios na constituição de Serápis, julgamos adequada a utilização do conceito de

\footnotetext{
${ }^{2}$ Data de acesso: 10/04/2020, às 20:00.
} 
"emaranhamento material", do arqueólogo Philip Stockhammer, no qual o autor compreende que um objeto "emaranhado" é resultado do contato entre duas ou mais culturas que se alteraram e formaram um "novo". Dessa forma, partimos da hipótese de que Serápis é resultado do contato e emaranhamento das religiões egípcia e grega.

O Egito greco-romano, oriundo das dominações greco-macedônica e romana, constitui um assunto com vários aspectos complexos a serem trabalhados. Quando várias culturas passam a conviver em um mesmo território, nem sempre é possível pôr em evidência as relações sociais que se estabelecem. Todavia, no campo da religião uma série de relações complexas entre as divindades nativas e, sobretudo, as gregas, podem ser observadas. Muitas identificações entre divindades egípcias não são recentes, mas advêm do período faraônico. Contudo, destaca-se o fato de que essa amálgama se intensificou nos períodos helenístico e imperial romano.

Quando tratamos da religião nesse contexto multicultural é notória a coexistência e o diálogo de vários cultos e práticas religiosas. Os cultos egípcios tradicionais persistiram durante os períodos ptolomaico e romano; um exemplo disso é o culto isíaco, o qual desfrutou de uma crescente popularidade entre os gregos. Os governantes estrangeiros eram retratados como faraós nos relevos das paredes dos templos egípcios e a mumificação era praticada em larga escala. Porém, enquanto os deuses funerários egípcios tinham uma maior presença nas tumbas e na iconografia de máscaras e caixões - como era o caso de Osíris, Ísis, Néftis e Anúbis - houve também uma assimilação de divindades de outros panteões, sobretudo do grego, ao panteão egípcio, principalmente no campo que se denomina de religião popular.

É o caso das estatuetas de terracota que representam divindades egípcias, gregas e asiáticas as quais eram destinadas não só a práticas religiosas populares, como os exvotos depositados em santuários, mas também eram encontradas em ambiente doméstico e mesmo em tumbas, sobretudo na região do Fayum, onde faziam parte do mobiliário funerário. Sobretudo na região do Fayum. Entre essas representações de divindades encontramos a do deus Serápis.

Esboçar o contexto histórico em que Serápis foi criado e disseminado pelo Mediterrâneo, além dos principais centros nos quais a cultura material desta pesquisa se encontra, será o nosso ponto de partida. Em seguida, serão abordados aspectos da religião egípcia, grega e romana, seus contatos e influências. Discutiremos, na sequência, acerca da matéria-prima utilizada na confecção dos artefatos selecionados neste estudo: a terracota. Por fim, iremos nos preocupar em analisar as terracotas de Serápis, partindo da 
hipótese de que o deus é resultado do emaranhamento das religiões egípcia e grega em seus atributos e funções.

\section{Egito greco-romano}

Quando Alexandre, o Grande entrou no Egito em 332 a.C., ele encontrou uma mínima resistência por parte dos persas. Com o fim dessa segunda ocupação persa (343 332 a.C.), mudanças radicais tiveram espaço, com ênfase na política, administração, economia e nas mais diversas esferas culturais (Castro, 2019, p. 22). Já era de longa data a relação entre o Egito e o mundo minóico-micênico. Desde o Médio Império (c.a. 2040 - 1782 a.C.), Egito e Creta mantinham relações comerciais, porém, por volta do século VII a.C. observa-se uma relação mais estreita com os gregos de maneira geral. Dois fatores, durante essa época, auxiliaram no aumento da presença helênica no Egito: a chegada de mercenários para servirem ao faraó Psamético I (XXVI dinastia, 664 - 610 a.C.) e a fundação da colônia grega de Náucratis, localizada no delta do Nilo. Com a conquista de Alexandre (332 a.C.) e a instituição de Ptolomeu como governante (305 a.C.), houve um abrupto crescimento de imigrantes gregos no Egito (Vasques, 2000, p. 7).

Em 331 a.C., Alexandre partiu rumo à Babilônia, e, nesse período, o Egito era apenas uma parte do vasto império macedônio, tendo sido conquistado do império persa para ser governado por um vice-rei com o título de sátrapa, cujo primeiro foi Cleômenes de Náucratis (Bowman, 1989, p. 22). Tal posição foi reivindicada por Ptolomeu, filho de Lagos, quando, da morte de Alexandre, em 323 a.C. Com a divisão do império de Alexandre feita por seus generais, Ptolomeu permaneceu no Egito. Em 305 a.C., assumiu o posto de rei e iniciou a dinastia ptolomaica, ou lágida, sendo notório em seu governo, desde o princípio, a legitimidade política fornecida pelo clero egípcio da cidade de Mênfis.

Segundo Manning (2019, p. 103-104), devemos pensar as instituições do governo ptolomaico não apenas como uma "herança" daquelas do Antigo Egito, pois ao longo do primeiro milênio a.C., o Egito foi governado por várias forças políticas externas que trouxeram novos elementos para compor o quadro administrativo. A criação da hierarquia administrativa de funcionários do Estado que fazia a ligação entre as vilas, as cidades e os centros regionais foram uma parte essencial do estabelecimento de uma ordem política ao longo de toda a história egípcia. O Novo Império (c. 1550-1070 a.C.) exerceu uma 
importante influência no sistema ptolomaico. Durante esses dois períodos, o Egito formou o núcleo de um império, a guerra era endêmica e as burocracias civil e militar alcançaram o seu ápice. Da mesma forma, as administrações Saita e Persa também influenciaram a estrutura da prática ptolomaica.

Com o domínio greco-macedônico houve uma considerável imigração de gregos para o Egito advindos de várias regiões, como: Grécia continental, Macedônia, Trácia, ilhas do Egeu e cidades gregas da Ásia Menor. A maior parte deles era composta por soldados, os quais recebiam um lote de terra, a clerúquia, em troca de seus serviços militares. Estes se concentraram, principalmente na nova capital, Alexandria, nas outras duas póleis situadas em território egípcio, Náucratis e Ptolemais, e na região do Fayum, uma depressão formada pelo Lago Moéris (hoje Birket Qarun).

As três póleis do Egito, Alexandria, Ptolemais e Náucratis tinham suas leis próprias, apesar de estarem sob controle real. Elas eram regidas pelo conselho de cidadãos (boule) ou por uma assembleia popular e seus habitantes estavam divididos em tribos e demos. A divisão do território egípcio continuou a mesma do período faraônico: os nomoi, que funcionavam como distritos administrativos, e as capitais dos nomos eram as metrópoles, cidades maiores administradas por um funcionário real.

Os gregos constituíam a elite do país, ocupando altos cargos administrativos no governo e adquirindo propriedades particulares como a clerúquia. No entanto, a divisão nítida entre gregos e egípcios se amenizou com o tempo. Os egípcios passaram a ser considerados pela administração lágida após a Batalha de Raphia, em 217 a.C., quando Ptolomeu IV necessitou dos indígenas em seu exército para vencer Antíoco III, o qual estava prestes a invadir o Egito. Segundo Vasques (2000, p. 10), no final do período ptolomaico, nos séculos II e I a.C., não era mais possível discernir entre egípcios e gregos. Muitos possuíam nomes duplos, gregos e egípcios, ou mesmo traduzidos de uma língua para outra, os quais usavam conforme a circunstância social. Os gregos usavam nomes egípcios para melhor se integrarem à cultura local, ao passo que os nomes gregos portados pelos egípcios podiam significar que esses tinham o interesse de compartilhar da cultura grega (Vasques, 2005, p. 13). Uma relação mais estreita entre gregos e egípcios se deu no meio rural, entre as camadas sociais menos favorecidas.

Os novos governantes investiram no uso de símbolos egípcios ligados à realeza, à figura do faraó e à tradição religiosa para se manterem no poder, mas também trouxeram uma máquina administrativa e burocrática nova para gerir as riquezas. Essa dinastia se manteve no poder até 30 a.C., sendo Cleópatra VII Filopátor a última regente descendente 
dos Ptolomeus. Nos últimos anos de governo ptolomaico, o poder estava debilitado. De fato, havia algum tempo que o Egito era um mero protetorado romano (Vasques, 2000, p. 11). As relações entre Egito e Roma remontam à época de Ptolomeu II Filadelfo (285 246 a.C.). Em decorrência de sua boa relação com Roma, os Ptolomeus conseguiram se manter no poder enquanto os latinos avançavam sobre as demais monarquias helenísticas. Um grande exemplo das estreitas relações entre Roma e Egito se deu com Cleópatra VII. Ela já havia se relacionado com Júlio César, o qual a pôs no trono do Egito, em 48 a.C., após guerrear com Ptolomeu XIII, seu irmão. Com a morte de César, posteriormente as alianças ocorreram entre Cleópatra e Marco Antônio, quem à época disputava com Otávio o controle das posses romanas (Castro, 2019, p. 24).

Com a derrota de Marco Antônio e Cleópatra, o Egito foi transformado por Augusto em uma província imperial, governada por um prefeito da ordem equestre, designado diretamente pelo imperador. Sendo a autoridade máxima, o prefeito era o comandante do exército, o chefe da administração civil e das finanças e o magistrado local. Era designado por um período de três anos e uma vez por ano viajava pelo país para fiscalizar as contas e ouvir as queixas do povo.

Durante o período de dominação romana, o Egito foi dividido administrativamente em três partes: a Tebaida (Alto Egito); a Heptanômia, que incluía o nomos arsinoíta (Médio Egito); e o Delta (Baixo Egito). Cada um era administrado por um epistratego, cargo esse oriundo do período ptolomaico e que possuía responsabilidades civis e militares, ficando restrito à esfera civil durante o período romano. O cargo administrativo de estratego também é proveniente do período ptolomaico, estando concentrado nos nomoi. Os censos foram a principal ferramenta de controle e captação de impostos, sendo implantados desde o governo de Augusto e estabelecidos em intervalos de 14 anos (Castro, 2019, p. 26).

No que tange à dominação política, não houve grandes mudanças com a alteração do governo. Todavia, o sistema de dominação romano era mais eficaz na cobrança de impostos e no controle sobre a população da província. Durante o período ptolomaico, visando atender às necessidades de ambas as populações grega e egípcia, existiam cortes de lei separadas, as quais operavam autonomamente em demótico e em grego. No período romano, de início, as leis em vigor eram uma mistura das leis egípcias e gregas. Com o tempo, essas foram sendo modificadas de acordo com a lei romana (Vasques, 2000, p. 13). 
Mare Nostrum, ano 2021, v. 12, n. 1 .

Alexandria, o Fayum e Antinoópolis são os três principais locais onde as terracotas desta pesquisa foram encontradas. Segundo Capponi (2011, p. 52), Alexandria foi fundada por Alexandre, o Grande em 7 de abril de 331 a.C. sobre uma aldeia chamada Rakótis (Bowman, 1989, p. 22), próximo do Delta do Nilo e de dois portos naturais: o Grande Porto para o leste e o Eunostos para o oeste. Alexandria foi planejada por Alexandre e pelo arquiteto Deinócrates de Rodes, os quais organizaram a cidade de acordo com os padrões da arquitetura grega. Em 320 a.C., Alexandria tomou o lugar de Mênfis como a nova capital do Egito Ptolomaico com o privilégio e status autônomo de pólis. No período romano, ela foi chamada de Alexandria ad Aegyptum (próxima do Egito) e, como uma típica cidade grega, estava culturalmente mais próxima de Atenas do que da zona rural egípcia.

Alexandria estava situada em um ponto estratégico entre o Vale do Nilo e o Mediterrâneo, uma posição que facilitava o transporte e a exportação de grãos do Egito para Alexandria e Roma. Além disso, rotas de caravanas que partiam do vale do Nilo ligavam o Egito aos portos do Mar Vermelho e do Extremo Oriente.

O nome Fayum significa “o mar”, “o lago”, nome dado no Novo Império (c. 15501070 a.C.) a uma depressão ocupada por um lago alimentado pelo Bahr Yussuf, um braço natural do Nilo. Durante o período greco-romano, foi um lugar pantanoso, com muitos peixes, aves e crocodilos. A prosperidade adveio à região com o sistema de irrigação implantado por Ptolomeu II Filadelfo no século III a.C. No decorrer dos períodos ptolomaico e romano, o Fayum foi uma região próspera, pelo menos até o século II d.C., quando houve um despovoamento em algumas aldeias devido à peste antonina. No século III d.C. as atividades retornaram e o local voltou a prosperar com a produção de vinho em larga escala. No começo do século IV d.C., várias aldeias começaram a não receber água e foram abandonadas de maneira completa ou parcial. Com o abandono das cidades, no século IV d.C. o deserto se propagou novamente e o governo egípcio somente voltou a investir na região no século XIX.

A região do Fayum é conhecida arqueologicamente pela produção de três achados predominantes: os retratos pintados, as figurinhas de terracota e os inúmeros papiros escritos, sobretudo em grego, mas também em hierático, demótico, copta, persa, aramaico, latim e árabe. Os pesquisadores dos séculos XIX e início do XX estavam interessados em coletar papiros (retirados das cartonagens das múmias) e objetos de arte. Assim, muitos dados acerca da planificação e arquitetura das cidades se perderam (Vasques, 2005, p. 72). 
Sob um antigo templo dedicado ao faraó Ramessés II, Adriano, em 130 d.C., fundou a cidade de Antinoópolis, em homenagem ao seu companheiro favorito Antínoo, o qual morreu afogado no rio Nilo quando o imperador viajava pelo Egito. Antínoo passou a ser associado a Osíris e a ser cultuado como um deus. O objetivo de Adriano era criar um centro de civilização grega no interior do Egito. A cidade foi construída em forma de trapézio e dividida em quarteirões seguindo o modelo de Alexandria. Ademais, possuía tanto órgãos governamentais de uma pólis grega, como também desfrutava de algumas vantagens da municipalidade romana, tais com um senado próprio. Antinoópolis foi escavada entre 1895 e 1910 por Albert Gayet, o qual explorou principalmente a parte relativa à necrópole romana. Porém, a pesquisa de Gayet não tinha respaldo científico, ficando difícil estabelecer a procedência correta dos objetos achados (Vasques, 2000, p. 17).

\section{Religião}

De acordo com Gama-Rolland (2017, p. 49-50), discutir a questão do contato com o divino, práticas religiosas e experiências religiosas no Egito Antigo é uma tarefa complexa. E isso se deve, em suma, à longa duração da história desse povo, com mais de três milênios. Existiam diferenças locais, na medida em cada cidade com seus templos e deuses, nem sempre estavam de acordo com o culto estatal. Além disso, o estado fragmentário das fontes escritas e arqueológicas, além da própria maneira "moderna" de "pensar a religião" por parte dos pesquisadores, tornam essa tarefa ainda mais desafiadora.

Tais crenças podem ser vislumbradas até o período imperial romano que, ao invés de serem extirpadas pelas novas, foram somadas, sobrepostas umas às outras. Os agrupamentos humanos que se uniram para formar o Estado egípcio possuíam cultos próprios e, no decorrer da história política do país, esses cultos se sobrepuseram. No sistema de crenças egípcias, cada cidade ou aldeia tinha um deus local e, de acordo com a predominância política de uma cidade, o deus "local" alçava a categoria de deus nacional (Vasques, 2000, p. 26).

Essas divindades tinham identidades e associações, aparecem de maneira proeminente nos textos religiosos no decorrer da história registrada do país e figuram como um conjunto altamente complexo de crenças religiosas. Dessa forma, é um equívoco simplesmente rotular uma divindade como o "deus de alguma coisa" e outra 
como o "deus de outra coisa", pois havia muitas identificações e inter-relações entre os membros do panteão (Shafer, 2002, p. 21). Outro aspecto importante a se considerar é, além da justaposição mencionada, a mudança da propria ideia de divindade, o que implica considerar a onipresença divina e a possibilidade que detinha de se manifestar em formas diversas. Dessa maneira, os vários nomes e formas físicas das divindades exprimem a presença universal do divino em todas as suas manifestações terrestres.

Segundo Traunecker (em Vasques, 2000, p. 26), as diversas imagens míticas do mundo, ainda que contraditórias, poderiam ser justapostas porque a função prevalecia sobre a forma. O mito de Osíris é um exemplo, uma vez que seu fundamento é universal, ou seja, sua morte e ressurreição podiam representar todos os fenômenos cíclicos, fossem eles a cheia do Nilo, a vegetação, a vida ou a morte.

Os templos egípcios eram locais sagrados isolados por grandes muros. A entrada principal era constituída por uma fachada composta por dois pilones, portais monumentais que simbolizavam as montanhas do horizonte. Entre os pilones e o edifício havia um corredor, o qual poderia conter estátuas e altares e que desembocava em grandes salas com o teto sustentado por colunas, chamadas de hipostilas. A partir dessas salas externas seguiam-se outros aposentos até se chegar em uma pequena capela onde a estátua do deus ficava guardada dentro de um tabernáculo de pedra ou granito (Vasques, 2000, p. 26). Outras salas contíguas à capela eram usadas no culto de deuses secundários e as câmaras laterais eram utilizadas como depósitos de objetos de culto. Além disso, outras construções geralmente eram anexadas ao edifício principal.

A religião privada tinha como função principal a solução de vários tipos de problemas. Era guiada pela chamada religião de piedade, na qual o adorador estava interessado em obter favores da divindade, cuja função principal era propiciar a prosperidade. A maior parte dos testemunhos da piedade pessoal datam do Novo Império (c. 1550-1070 a.C.) e do Período Tardio (712-332 a.C.). As devoções individuais estavam centradas em divindades locais que protegiam uma região específica. Santuários eram procurados para oferendas e consultas oraculares, ao passo que os santuários pequenos eram requisitados como depósito de objetos votivos em agradecimento por algum benefício prestado pelo deus.

Capelas destinadas a cultos locais eram populares no Egito ptolomaico e romano. Constituíam-se de edifícios modestos cuja entrada era ornada por guirlandas de flores e folhas. Em um pequeno pedestal no interior ficava a estátua da divindade. Devido ao tipo de material perecível utilizado na construção das casas durante o Egito faraônico, é difícil 
estabelecer a existência de cultos domésticos no decorrer desse período. Alguns dos poucos exemplos que conhecemos advêm de vilas, como a dos trabalhadores de Deir elMedina, responsáveis pela construção das tumbas do Vale dos Reis durante o Novo Império.

Segundo Dunand e Zivie-Coche (1991, p. 214), quando a dinastia dos lágidas tomou o poder político no Egito, eles conduziram uma política religiosa "flexível" no que tange aos cultos tradicionais. Não obstante, eles estiveram envolvidos na origem de uma criação religiosa da qual o impacto, no início, não se observou muito bem, mas que se tornou mais preponderante com o passar dos anos tanto dentro como fora do Egito: o culto de Serápis.

A origem desse culto, desde os primeiros momentos, esteve rodeada por lendas. O relato mais difundido é o de Plutarco (De Iside et Osiride, 28), o qual conta que Ptolomeu I Sóter sonhou que diante dele apareceu uma "estátua colossal" de um deus residindo em Sínope. Esse deus "quem ele nunca tinha visto antes", ordenou que Ptolomeu levasse a sua imagem para Alexandria. Quando seus sacerdotes a viram, associaram-na ao deus grego Hades, dando-lhe o nome de Serápis, "que é o nome de Hades entre os egípcios" (Dunand \& Zivie-Coche, 1991, p. 214).

Longos debates se sucederam para tentar explicar a origem do nome Serápis. De qualquer forma, é provável que o nome seja de origem egípcia (Dunand \& Zivie-Coche, 1991, p. 215). Ponderando sobre a "natureza" do deus, Plutarco escreveu que "a maior parte dos sacerdotes dizem que Osíris e Ápis foram fundidos juntos em uma única entidade" (Plutarco, De Iside et Osiride, 29). Serápis afigura-se como a transcrição grega do nome egípcio Osíris-Ápis, o qual era uma divindade adorada em Mênfis - local que durante o Período Tardio contava com uma considerável população grega (Dunand \& Zivie-Coche, 1991, p. 215). Certamente essa população grega tinha pleno conhecimento do culto de Osíris-Ápis e, assim, podemos inferir que provavelmente a escolha do nome Serápis não tenha sido coincidência, ou mesmo uma simples invenção (Neiva, 2017, p. 28). Cogitou-se, igualmente, que teria ocorrido a associação desse novo deus, ligado à imagem de Hades, a um deus pré-existente, Osíris-Ápis e sua ressignificação.

Alexandria constituía-se como uma pólis poliglota e que abrigava uma população que, além dos gregos, incluía egípcios nativos, sírios, persas, anatólios, indianos e judeus, para citar alguns. No início da administração lágida, o matrimônio entre gregos e nãogregos era proibida e cargos na administração civil e militar só podiam ser exercidos por gregos e macedônios. Todavia, a segregação étnica apoiada pelos Ptolomeus 
provavelmente se restringia à elite da população e não foi muito extensa se comparada à duração dessa dinastia (305 - 30 a.C.), sendo encerrada ao fim do século III a.C. Os gregos das camadas mais subalternas, ainda que desfrutassem de alguns privilégios, tinham um contato mais próximo com a população egípcia e sua cultura (Vasques, 2000, p. 29).

Com o início da dominação romana (30 a.C.), houve uma nova estratificação social. O grupo detentor de privilégios seria o dos cidadãos romanos, logo em seguida vinham os gregos, os judeus e, por fim, os egípcios. A população não-romana era classificada socialmente em dois grupos: os cidadãos das póleis (Alexandria, Náucratis, Ptolemais e Antinoópolis) e os egípcios. Esse último, por sua vez, incluía todos aqueles que não pertenciam a uma pólis, até mesmo os gregos que viviam na chôra.

Os cultos de Ísis e Serápis, durante o período ptolomaico, seguiam a forma e o ritual gregos, sobretudo em Alexandria e nas áreas de colonização greco-macedônica. Mas é preciso ressaltar que o culto isíaco tradicional permaneceu relevante na chôra, principalmente em seu aspecto funerário, com Ísis no papel de irmã carpideira de Osíris. Além disso, a religião popular permite uma maior abertura na relação homem-divindade, pois tal contato se estabelece mais estreitamente, sem uma intervenção direta do templo e de práticas que extrapolam os rituais “oficiais" (Gama-Rolland, 2017, p. 57-61). É provável que o culto tradicional de Ísis continuasse ocorrendo nas propriedades particulares, mesmo em uma zona de forte influência helênica.

No decorrer do período imperial romano, o culto de Ísis adquiriu uma grande popularidade e isso se reflete na quantidade de peças de terracota analisadas nesta pesquisa. Ísis, dentre todos os deuses que foram incorporados no panteão romano, possui um lugar de destaque. Segundo Cunha (2016, p. 121), Ísis é considerada uma das divindades mais populares, não no sentido de estar relacionada apenas à população menos privilegiada de Roma, mas sim pelo seu alcance ao longo do mundo romano.

Quando pensamos nos deuses emaranhados em Serápis podemos reforçar a ideia de um deus com a função de legitimador/protetor da nova dinastia: Osíris, Hades, Ápis, Zeus, Hélio, Asclépio e Dioniso, citando os principais. Todos esses foram deuses proeminentes em seus respectivos panteões e, no caso de Osíris, Hades e Zeus, deuses que governaram uma parte do cosmos: Osíris como senhor do Duat, - portador do cajado heqat e do açoite nekhakha, insígnias da realeza e da autoridade do faraó, e como soberano que preside o julgamento do recém-falecido para determiná-lo merecedor ou não da vida no além; Hades como espaço físico e senhor do submundo, de certa forma, espelho ctônico de seu irmão Zeus; por fim Poseidon, como senhor dos mares. Ao resgatar 
a estátua de Serápis e tê-lo por deus guardião da nova capital do Egito, Alexandria, Ptolomeu I se colocou na posição de legítimo faraó, protetor da Verdade, da Justiça e do Equilíbrio, enfim, de Maat. Em contrapartida, todos os habitantes do Estado egípcio deviam ao novo faraó lealdade e respeito a uma hierarquia divinamente respaldada.

\section{Proporção Entre Ísis e Serápis}

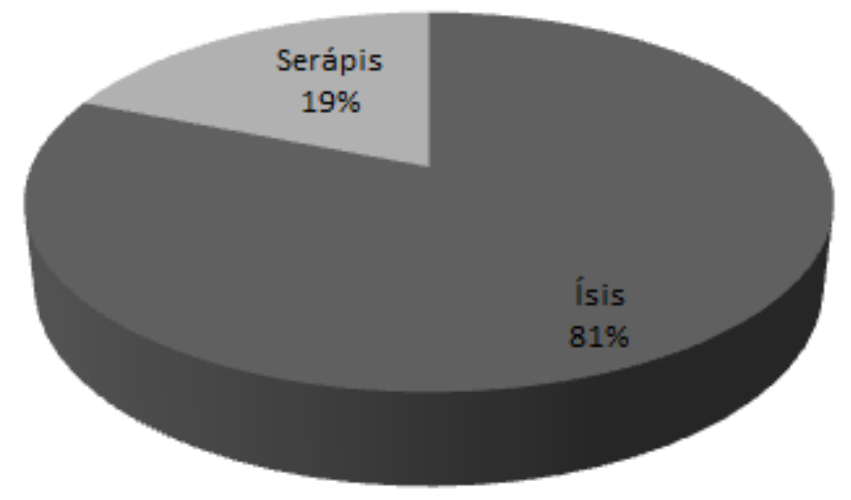

Gráfico 1. Demonstra a proporção entre Ísis e Serápis relativas ao período do Egito greco-romano. O gráfico ilustra a proporção da cultura material relativa a Ísis (150 peças) e a Serápis (35 peças), reforçando a hipótese da maior presença do culto isíaco nos meios populares, sendo esse um dos resultados da pesquisa de nossa Iniciação Científica. Para a composição deste gráfico, excepcionalmente, foram utilizados apenas os livros Catalogue des Terres Cuites Gréco-romaines d'Égypte (1990) e Religion Populaire en Égypte Romaine (1979) de Françoise Dunand. Optamos por não incluir as peças da coleção online do Museu Britânico pela dificuldade de selecionar todas as peças de Ísis do site.

Fonte: Própria.

No primeiro século da administração ptolomaica, um forte controle de acesso aos cargos de administração estava em vigor, além do controle dos casamentos, o que desencorajava qualquer tipo de miscigenação entre gregos e não-gregos. Com isso, os principais postos do Estado egípcio estavam em posse de gregos e seus descendentes. Proponho que foi essa parcela da população que adotou o culto a Serápis em seu início, incentivando a população grega menos abastada social e economicamente, e assim restringindo-o a esses dois círculos sociais.

Os poucos fragmentos do culto popular de Serápis se encontram, quase em sua totalidade, em centros de maciça influência grega, seja nas póleis, como Alexandria e Antinoópolis, ou nas regiões do Fayum e do Delta do Nilo. A partir dos séculos II e I a.C. 
os cargos da administração civil e militar puderam ser ocupados pela elite egípcia nativa; além disso, houve a flexibilização das normas contrárias aos casamentos mistos. Em decorrência dessas resoluções, testemunha-se a ascensão de uma elite com forte ligação aos cultos egípcios tradicionais. Se supormos que tal elite não tenha adotado como de sua preferência o culto recém-criado de Serápis, mas o de Ísis em razão de sua grande importância entre seus ancestrais, isso explica em partes o motivo do culto a Ísis ter se tornado mais popular do que o de Serápis nos momentos finais do período ptolomaico e no início do período romano.

A representação iconográfica de Serápis foi criada no período ptolomaico, seguindo os moldes de divindades gregas, tais como Zeus, Hades e Asclépio. Foi retratado sob a forma de um homem, com barba, à semelhança de Zeus, usando chíton e portando em cima da cabeça o calathos (ou modius), atributo associado às divindades da fertilidade. Representado como deus do submundo, aparece sentado em um trono portando um cetro em uma das mãos e pousando a outra sobre a cabeça de cérbero tricéfalo. Serápis é, em só tempo, deus da fertilidade e da vegetação, como Osíris, soberano do submundo (cetro, cérbero e trono), como Hades, deus solar, assimilado a Hélio (podendo portar uma auréola) no final do século I d.C., deus curandeiro, como Asclépio, e protetor da navegação juntamente com os Dióscuros.

De acordo com Naether (2019, p. 440), estudiosos concordam que Serápis foi criado como um deus da abundância e da vida após a morte com o intuito de unificar as crenças gregas e egípcias. Ele não aparece com muita frequência na sua forma zoomórfica como as demais divindades egípcias (com exceção de Osíris). No panteão egípcio, Serápis foi equiparado a Osíris e assumiu muitas de suas funções, como o regenerativo. Contudo, os atributos ctônicos de Osíris permaneceram relevantes na chôra. O culto de Serápis é amplamente atestado ao longo do Império Romano, tendo desfrutado de grande aceitação. Do quarto século em diante a tríade Serápis-Ísis-Harpócrates foi igualada apenas pelo cristianismo no que se refere à sua difusão pelo Mediterrâneo.

\section{Terracota}

A Grécia foi o grande centro de produção de terracotas na Antiguidade, assim como as áreas sob a sua influência. No mundo grego, estatuetas de terracota foram feitas do Neolítico até o período imperial romano. Terracotas greco-romanas são pequenos artefatos escultóricos feitos de argila e que foram produzidos do terceiro século a.C. até 
o quarto século d.C. No geral, são distinguidos em estilo e motivo por uma mistura visível de elementos egípcios e gregos (Sandri, 2012, p. 630).

Em suma, a palavra terracota define um produto feito à base de argila, com diferentes níveis de depuração - compacta, fina, cor de rosa ou amarelada, sem cobertura de esmalte ou de verniz - que, na maioria dos casos, era pintada com uma cor viva aplicada antes ou depois da queima. Era um produto fabricado em grande quantidade por ter um custo relativamente baixo. As estatuetas de terracota produzidas no Egito consistiam, em sua maioria, de imagens humanas, de divindades e de animais, cujos vestígios arqueológicos são encontrados principalmente em santuários, tumbas e residências (Vasques, 2000, p. 47).

Outro tipo de cultura material muito presente nesta análise são as lamparinas de terracota. No passado, o estudo desse artefato se concentrava apenas na aplicação de métodos tradicionais: a tipologia e a cronologia. Atualmente, tal abordagem ainda persiste e pouco tem-se feito para superar esse quadro e compreendê-las em termos de sua fabricação, significado religioso e tecnológico. No entanto, mais recentemente, novas abordagens como a análise química e petrográfica das pastas têm sido utilizadas para compreender a natureza do comércio de lamparinas e esclarecer a relação entre as oficinas e os centros regionais de produção (Bastos, 2016, p. 16-17).

Para a fabricação de terracotas era preciso obter uma argila de boa qualidade, indispensável para garantir que a peça não se quebrasse ou apresentasse defeitos depois da queima. Com o intuito de inibir a contração e rachaduras no produto final eram misturados areia e pequenos seixos na argila. A modelagem à mão era o método mais arcaico e simples na fabricação de peças de terracota. $\mathrm{O}$ torno poderia ser utilizado para fazer um corpo cilíndrico, ao qual era, posteriormente, acrescentada uma cabeça ou outros acessórios.

Apesar de não excluir o uso das técnicas mais antigas, o uso do molde se tornou o método mais popular a partir do século V a.C. Antes de ir para o forno, a peça poderia sofrer uns retoques finais. Depois da queima, a terracota era pintada, recebendo ou não antes da coloração uma camada de leite de cal ou engobo (argila branca).

De acordo com a finalidade da estatueta o seu acabamento poderia ser mais ou menos cuidadoso. Na maioria dos casos, os produtos feitos em larga escala não apresentavam retoques. As terracotas colocadas em tumbas ofereciam uma variedade maior de motivos e frequentemente eram retocadas; ao contrário, por exemplo das 
Mare Nostrum, ano 2021, v. 12, n. 1 .

estatuetas colocadas como ex-votos em templos, as quais eram marcadas pela representação de tipo um único uniformemente repetido.

Sandri (2012, p. 643) argumenta que a cultura material feita de terracota não se destinava unicamente à população com um menor poder aquisitivo. Ela defende que esses objetos também estavam presentes de maneira considerável nas camadas mais abastadas do Egito romano sendo, inclusive, encontradas em residências luxuosas, o que assinala uma defasagem da interpretação anterior, na qual a terracota seria um material necessariamente popular $\mathrm{e}$, por isso, ligado às pessoas mais pobres da sociedade.

Os artefatos de terracota presentes neste estudo foram produzidos com base na técnica da terracota moldada. Essa técnica foi introduzida em Alexandria no período ptolomaico e, no período romano já havia se disseminado por todo o Egito. As terracotas das quais tratamos foram divididas em dois tipos: as produzidas em Alexandria, mais bem fabricadas, mais finas e com bom acabamento, e as produzidas no restante do Egito (Vasques, 2000, p. 52). Na chôra, as peças produzidas durante o período imperial romano tinham um caráter mais grosseiro, sendo, provavelmente, destinadas a uma camada social menos abastada, em boa parte constituída por camponeses.

\section{As terracotas de Serápis}

No que tange a metodologia empregada na pesquisa para composição do corpus documental aos moldes de catálogos arqueológicos, a cultura material deve se encaixar em três requisitos: a terracota tem que ser a matéria-prima, ter sido feita ao longo dos períodos ptolomaico e romano e conter uma representação, antropomórfica ou não, de Serápis. Tomando tais requisitos como base, foram selecionadas todas as peças contidas nos livros Religion Populaire en Égypte Romaine (1979) e Catalogue des Terres Cuites Gréco-romaines d'Égypte (1990), ambos da autoria de Françoise Dunand e da coleção online de acesso público do Museu Britânico.

A organização das peças aos moldes de um catálogo arqueológico é fundamental para o controle, estruturação, análise e interpretação dos artefatos. Os tópicos eleitos para compor o corpus foram: inventário, entrada, proveniência, material, tipo, cor, dimensões, conservação, datação, posição, descrição e bibliografia. Após esta primeira organização, a cultura material foi disposta em categorias de análise e subtópicos definidos pelo autor com base nas semelhanças ou diferenças apresentadas pelas peças. Os tópicos criados foram: I - estatuetas de Serápis entronado; II - lamparinas e alças de lamparinas com 
representações de Serápis; III - bustos de Serápis; IV - fragmentos de cabeça de Serápis; V - representações antropozoomórficas e zoomórficas de Serápis; e VI - representações de Serápis em peças variadas. Com o corpus concluído, iniciou-se a análise de tipo estatística, na qual se procurou evidências sobre o local de origem, a tipologia, os atributos que Serápis têm na cabeça e as divindades que aparecem ao seu lado.

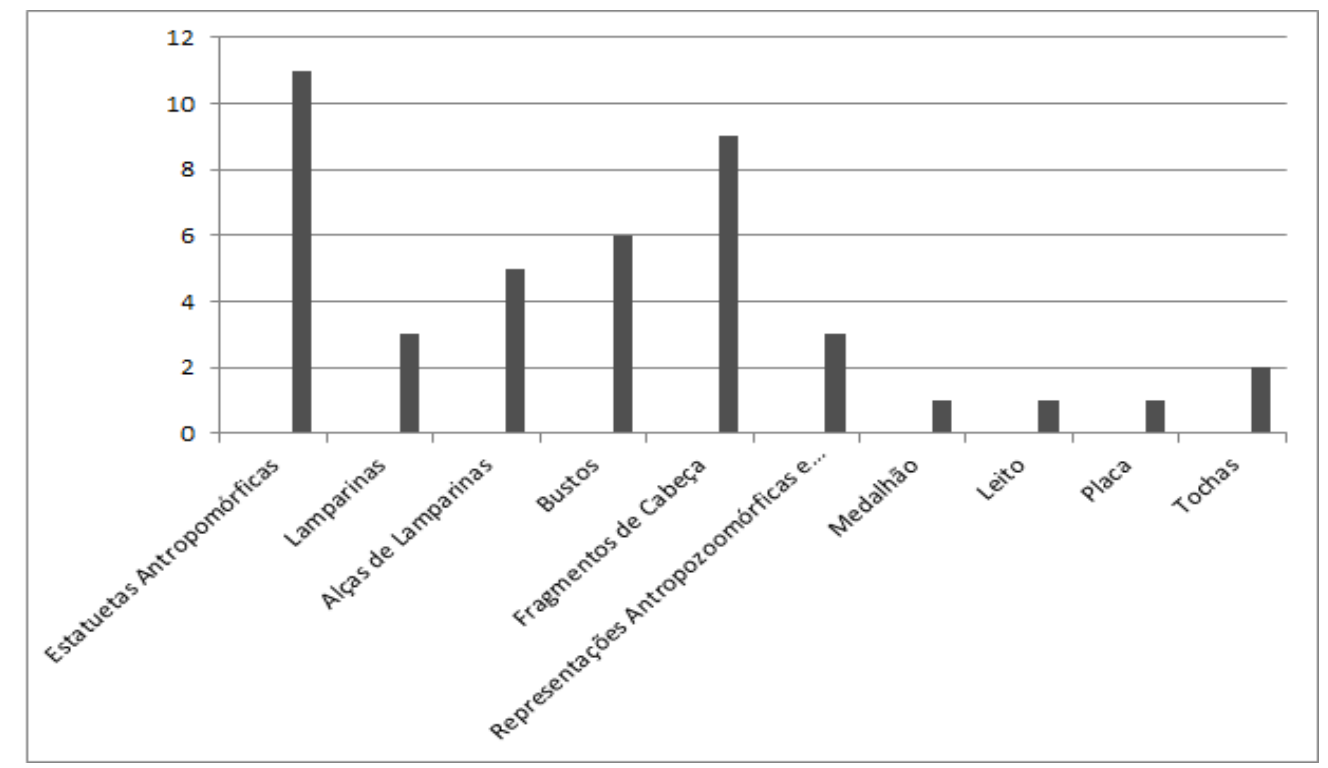

Gráfico 2. Detalhe das categorias de artefatos utilizados na pesquisa e sua quantidade. $\mathrm{O}$ gráfico demonstra as fontes materiais utilizadas na pesquisa e sua quantidade, em um total de 42 peças distribuídas em dez subcategorias que detalham mais as categorias criadas para a elaboração do corpus documental: I - Estatuetas de Serápis entronado; II - Lamparinas e alças de lamparinas com representações de Serápis; III Bustos de Serápis; IV - Fragmentos de cabeças de Serápis; V - Representações antropozoomórficas e zoomórficas de Serápis; e VI - Representações de Serápis em peças variadas.

Fonte: Própria.

A teoria que utilizamos na interpretação da cultura material é a do “emaranhamento material”, proposta pelo arqueólogo alemão Philipp Stockhammer (2012) como uma alternativa ao conceito de "hibridização", tal como desenvolvido por Homi Bhabha. A palavra híbrido teria uma conotação biológica na origem, enquanto o termo "hibridização" está vinculado ao contexto político nos estudos pós-coloniais. Stockhammer (2012, p. 47) defende o uso do termo "emaranhamento" no lugar "hibridização", uma vez que seria uma versão despolitizada do conceito de Bhabha.

Para verificarmos se a cultura material é fruto de emaranhamento ou não, é preciso elaborar um modelo do que é uma entidade, no sentido de cultura material. Ou seja, é 
preciso definir o que é um objeto micênico, celta, egípcio, etc. De acordo com Stockhammer, estamos considerando a cultura material do ponto de vista ético do pesquisador. Em outras palavras, as diferenças que o pesquisador ressalta devem remeter a uma provável percepção passada dos indivíduos. Essas entidades são modelos mentais usados como modelo analítico. Esse momento de encontro da construção e percepção da alteridade e da diferença, é o impulso central que tem lugar nos espaços liminares, os quais o autor visualiza como situações e espaços que não estão limitados a uma área geográfica. Além disso, define "espaços liminares" como espaços de encontro, independentemente de onde esse encontro aconteça (Stockhammer, 2012, p. 49).

Stockhammer (2012, p. 50) propõe dois tipos de emaranhamento: o relacional e o material. Na primeira variável um objeto estrangeiro pode ser usado em outras culturas, sofrendo um processo de ressignificação. Nesse caso, não houve nenhum tipo de alteração no objeto, o que se alterou foi a prática social em relação a ele. É importante ter em mente que os processos que conduziam ao estado de emaranhamento relacional provavelmente não eram guiados apenas por escolhas pessoais, mas também por regras e rituais da sociedade em questão.

Com o processo de emaranhamento material, há o desenvolvimento dos objetos emaranhados, os quais estão associados ao processo de criação material. As energias criativas originalmente liberadas pelo encontro e ampliadas dentro do processo de apropriação resultam na criação de um novo objeto que combina o familiar com o estrangeiro. Tal objeto não é o resultado de uma continuidade local, mas das trocas com o outro. Mesmo que um objeto tenha perdido seu contexto original e, dessa maneira, tenha perdido a informação da prática social, ele pode ser identificado como um objeto emaranhado, uma evidência de emaranhamento na Arqueologia.

As entidades postas em evidência para a compreensão de Serápis como uma divindade emaranhada são a egípcia e a grega. Para além da origem de seu nome, Serápis carrega em si variados atributos do sincretismo Osíris-Ápis, como veremos a seguir. A cidade de Mênfis abrigava um touro chamado Ápis, o qual tinha atributos especiais e, na condição de arauto e $b a^{3}$ de Ptah, propiciava serviços oraculares a devotos em busca de respostas para seus anseios. No momento em que Ápis morria, ele recebia cerimônias fúnebres faustosas no cemitério que abrigava várias gerações de seus antepassados, o

\footnotetext{
${ }^{3}$ Não existe uma tradução precisa para essa palavra, o $b a$ é um dos componentes espirituais do homem, dos deuses e dos animais. Responsável pela individualidade, é um elemento ativo e dinâmico que se separa do corpo após a morte.
} 
Serapeum. Esse local também detinha um templo dedicado à sua versão sincrética com Osíris, Osíris-Ápis, deus funerário e senhor de toda necrópole de Saqqara (Duarte, 2010, p. 18).

Nessa época e em decorrência de sua associação aos aspectos funerários da religião egípcia, o touro Ápis também compartilhava qualidades com o deus sol Rê. Esses atributos funerário, ctônico e solar, são aspectos centrais no culto de Serápis. É manifesto que tais características de deus do submundo são provenientes, também, de Hades, mas supomos que os atributos ligados ao sol advenham de Osíris-Ápis e, nos períodos ptolomaico e romano, tenham sido emaranhados com os de Hélio.

A entidade grega se manifesta, além dos atributos ctônicos citados anteriormente, na constituição iconográfica de Serápis. Ele é representado como um homem maduro, com cabelos encaracolados e barba abundantes, aos moldes de Zeus e Asclépio. Ele também é representado com um calathos na cabeça, ligando-o às divindades distribuidoras de bens e à fertilidade. O cão guardião do Hades, Cérbero, também aparece junto a Serápis.

Criado como um deus da corte ptolomaica, Serápis se popularizou entre a população greco-macedônia e, posteriormente, romana. No que diz respeito às estatuetas de Serápis entronado, dois padrões aparecem: o primeiro apresenta Harpócrates ao seu lado; o segundo, Cérbero. Quando Harpócrates está ao seu lado, Serápis aparece com a coroa atef ${ }^{4}$ em todos os casos - com exceção de duas imagens, nas quais as coroas estão fragmentadas no topo. Como atef é a coroa de Osíris, talvez essa seja a imagem mais ligada à realeza, dando ênfase à coadunação de Serápis e Osíris em uma única divindade e ligando-o à tríade Serápis-Ísis-Harpócrates. Harpócrates e Ísis, nessa ordem, são os deuses que mais aparecem no corpus documental associados a Serápis, o que reforça a importância da tríade mencionada. É importante pontuar que todas essas estatuetas carregam cornucópias, as quais simbolizam abundância e prosperidade.

\footnotetext{
${ }^{4}$ Coroa do deus Osíris e do deus Herishef com o formato de mitra ladeada por plumas de avestruz e, às vezes, com o disco solar em seu topo. Pode possuir também dois cornos de carneiros e o uraeus (Brancaglion, 2003, p. 111).
} 


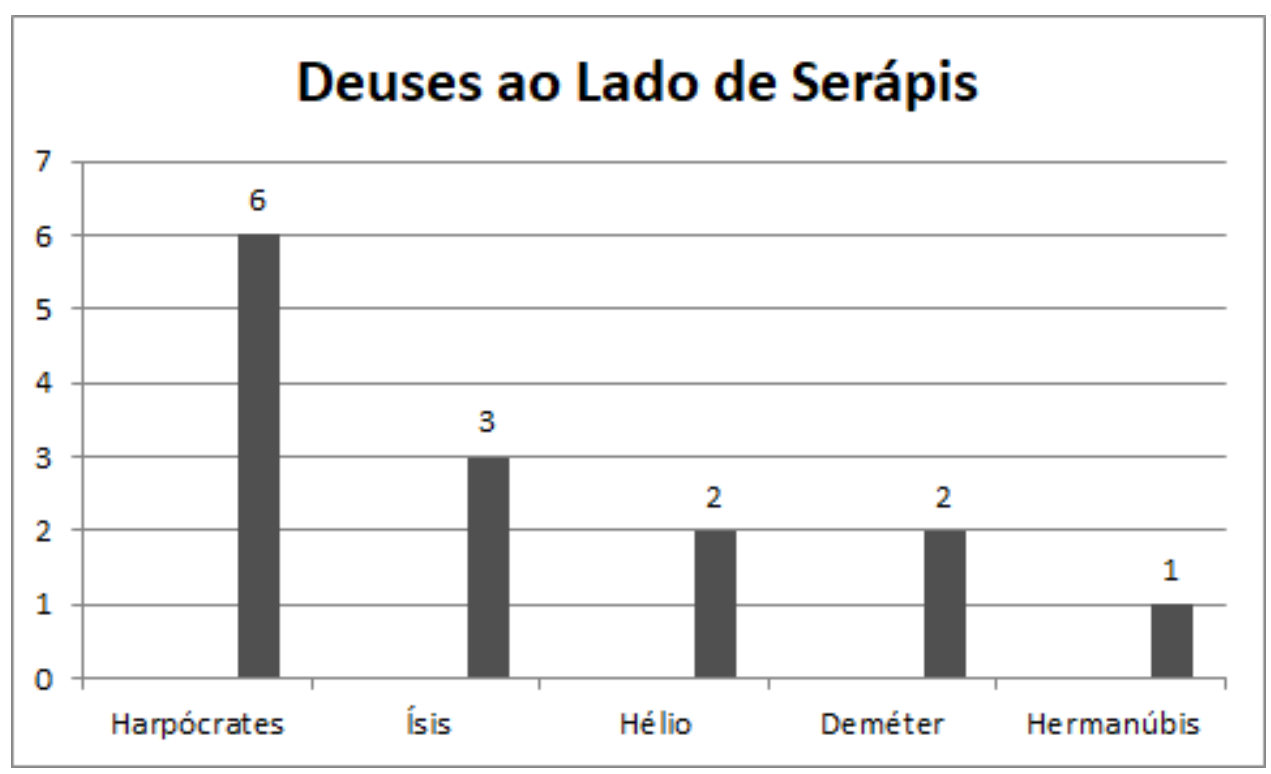

Gráfico 3. Frequência dos deuses que aparecem com Serápis. O gráfico aponta quais são as divindades que mais aparecem associadas a Serápis.

Fonte: própria.

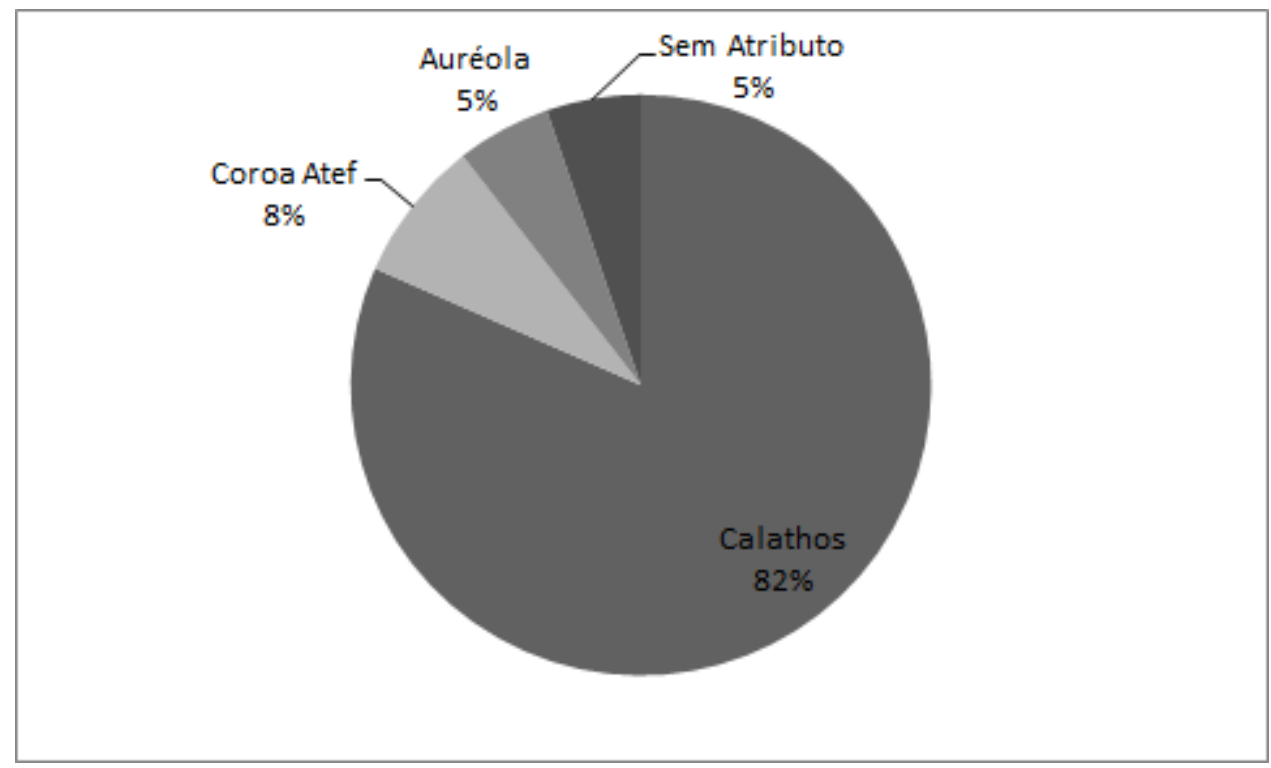

Gráfico 4. Presença do calathos, coroa atef, auréola ou ausência de atributo sobre a cabeça. O gráfico demonstra quais atributos estão sobre a cabeça de Serápis. Para a elaboração deste gráfico, das 42 peças totais, foram utilizadas 38 , pois as demais peças estavam quebradas na cabeça, não permitindo incluí-las em qualquer grupo para o cálculo. Dessa forma, das 38 peças, 31 têm o calathos, 3 a coroa atef, 2 a auréola e 2 não têm qualquer atributo sobre a cabeça. Podemos observar uma preponderância do atributo ctônico ligado ao calathos.

Fonte: Própria 
Quando Cérbero está ao lado de Serápis, ao invés da coroa atef o calathos aparece em $100 \%$ dos casos, à exceção das vezes em que a estatueta não está fragmentada no topo da cabeça; e em todas o deus segura um cetro. Representação esta a mais ligada a Serápis como deus do submundo, com ênfase nas características ctônicas do deus.

Serápis também pode ser associado a Hélio e, assim como Rê, ele agrega a uma só vez os atributos de um deus solar (auréola) e ctônico (fertilidade da terra, cura de males, abundância das colheitas), uma vez que Rê, nos textos funerários egípcios, é descrito navegando no céu na barca do dia e, à noite, viajando pelo mundo inferior na barca noturna. Durante essa viagem dá-se uma relação entre Rê e Osíris, os quais acabam se "fundindo" de forma que Osíris torna-se o corpo do deus e Rê seu ba (Vasques, 2005, p. $65)$.

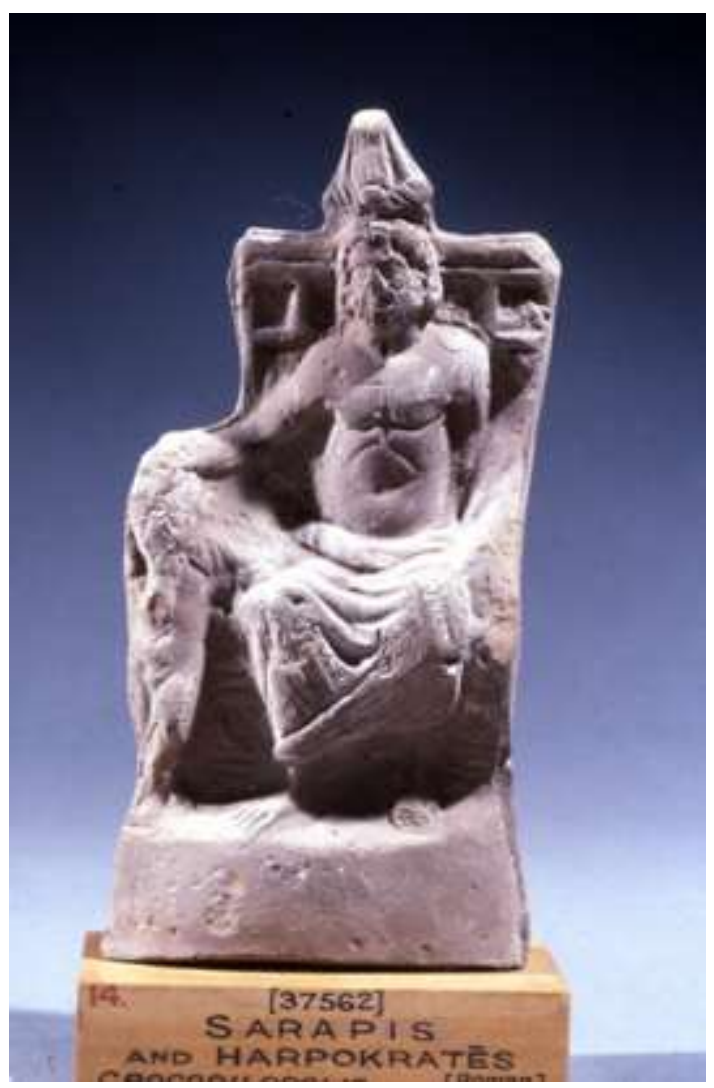

Figura 1. Serápis entronado com Harpócrates ao seu lado.

Fonte: British museum. (2020, 16 de agosto). Collection online. Londres. Recuperado de: https://research.britishmuseum.org/research/collection_online/collection_object_details.aspx?ob jectId $=127085 \&$ partId $=1 \&$ page $=1 \&$ searchText $=$ Sarapis .

Nesta pesquisa, a fonte material mais recorrente são as "estatuetas antropomórficas" de Serápis (vide gráfico 2). E nelas observam-se dois padrões: Serápis entronado utilizando a coroa atef e com Harpócrates ao seu lado, e Serápis entronado 
utilizando o calathos e com Cérbero ao seu lado. A coroa atef se associa a Harpócrates e o calathos a Cérbero. No primeiro caso, talvez seja para enfatizar o emaranhamento entre Serápis/Hades-Osíris em seu papel como pai de Harpócrates e marido de Ísis. Na segunda representação não há “emaranhamento material”, uma vez que é a entidade grega se sobrepõe na materialidade. ${ }^{5}$ Serápis tem seu papel como soberano do submundo associado a Hades, que, por sua vez, aparece destacado —, além de possuir atributos ctônicos ligados à fertilidade e abundância.

Na figura 1, há a representação de Serápis entronado com Harpócrates ao seu lado, pertencente à categoria de estatuetas de Serápis antropomórfico. A estatueta apresenta emaranhamento entre as entidades grega e egípcia em sua composição material, visível pela própria representação de Serápis ao estilo grego, por meio do uso do himation e cabelos encaracolados, por exemplo, bem como por seus atributos egípcios, tais como a coroa atef com chifres de carneiro retorcidos sobre sua cabeça. Há alguns danos superficiais, mas a estatueta está bem preservada. Essa peça foi fabricada em duas metades separadas e as costas são lisas. A hipótese para a explicação de tal fato é a de que a peça deveria estar encostada na parede de um nicho, provavelmente atuando no culto doméstico como guardião do lar e criando uma ponte divindade-devoto.

Serápis está sentado em um trono, com um manto (himation) sobre os membros inferiores e a parte superior do corpo nua. Ele usa uma coroa atef, com disco e chifres torcidos, talvez associando-o a Amon por meio de seus atributos solares. Ele é barbudo, simbolizando um homem maduro. Uma cornucópia é segurada na dobra do braço esquerdo, reforçando seu papel como deus ligado à fertilidade e à prosperidade. Ele repousa a mão direita na cabeça de Harpócrates, que se inclina com as pernas cruzadas contra o braço do trono. Os detalhes de Harpócrates são obscuros e danificados, mas ele tem o dedo na boca e, aparentemente, tem uma cabeça raspada com uma trava lateral. Ele também parece estar nu, exceto por um manto sobre o ombro esquerdo. $\mathrm{O}$ trono tem detalhes de sua construção na borda superior e nas pernas e a base está lisa e curvada na frente.

A figura 2 é um fragmento de uma cabeça oca de Serápis composta em terracota, quebrada de uma estatueta ou, o que é mais provável, de um busto, com um calathos

\footnotetext{
${ }^{5}$ Isso não significa que Serápis não seja um deus emaranhado. O conceito de emaranhamento está sendo utilizado além do material. Serápis emaranha os atributos e funções de divindades gregas (Hades, Zeus, Asclépio, Dioniso, Hermes) e egípcias (Osíris, Ápis), sendo o resultado de um novo a partir das duas entidades. Todavia, o próprio emaranhamento material também pode ser observado nas figuras 1 e 3.
} 
decorado com ramos, provavelmente de oliveira, na frente e nas laterais. A peça, feita em argila cinza-azulada, foi modelada ao redor e recebeu inclusões brancas com enxerto marrom avermelhado em geral.

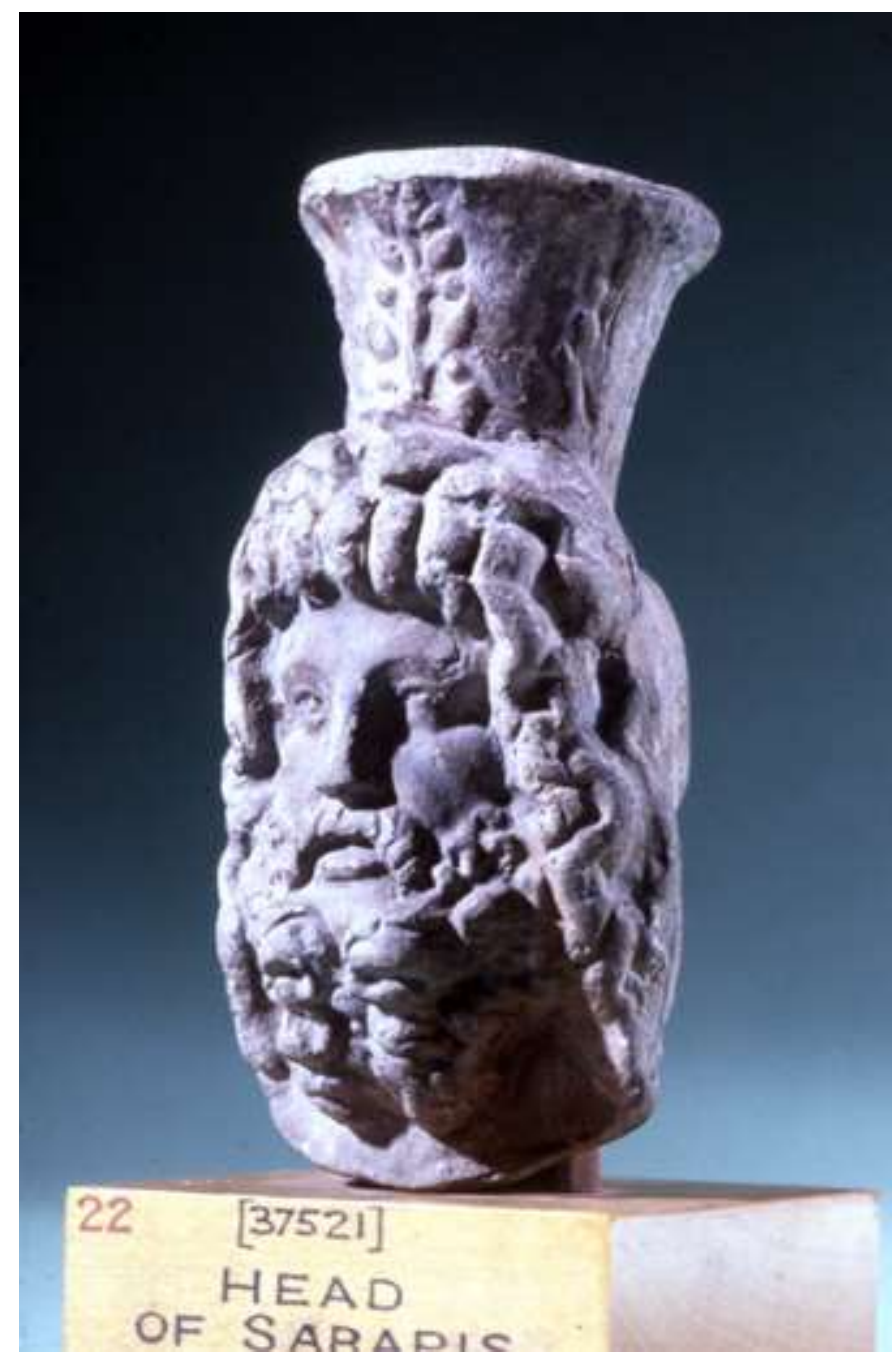

Figura 2. Cabeça de Serápis.

Fonte: British museum. (2020, 16 de agosto). Collection online. London. Recuperado de: $<$ https://research.britishmuseum.org/research/collection_online/collection_object_details.aspx?o bjectId=127130\&partId=1\&page $=2 \&$ searchText $=$ Sarapis $>$.

Esta figura dialoga com a primeira na medida em ambas trazem objetos diferentes na cabeça. A primeira imagem porta o atributo egípcio da coroa atef com chifres de carneiro retorcido. Por sua vez, a estatueta, ou busto, que agora apresentamos poderia figurar não só no contexto do lar, assim como a outra, mas também poderia ser um exvoto depositado em um templo ou ainda ter atuado no contexto funerário com a função de trazer abundância para que o morto não sentisse fome no além. Essa última talvez seja a hipótese mais adequada, uma vez que o calathos aparece associado a Cérbero no 
contexto das estatuetas, além de ser um atributo ligado à vegetação e à prosperidade, ambos elementos ctônicos associados a Osíris.

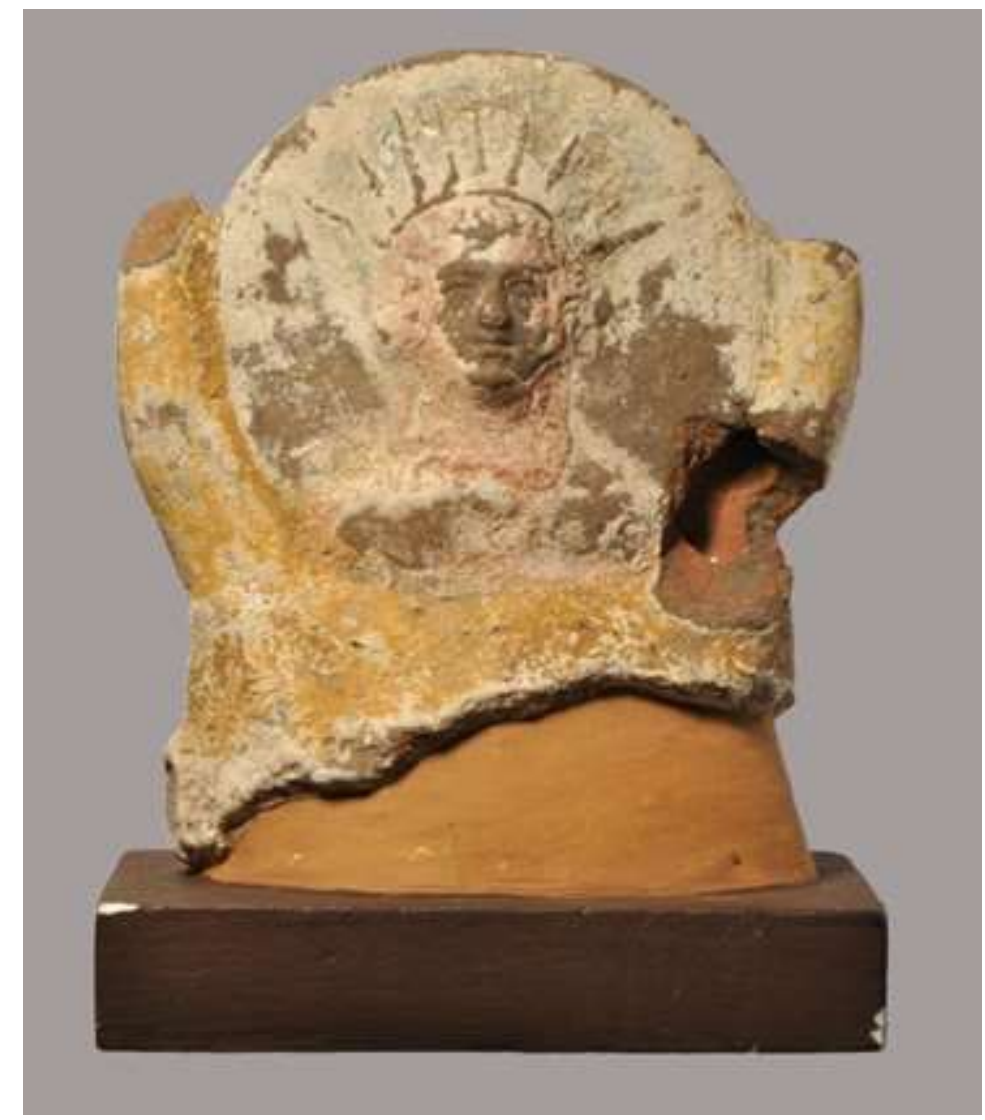

Figura 3. Fragmento de touro Ápis.

Fonte: British museum. (2020, 16 de agosto). Collection online. Londres. Recuperado de: $<$ https://research.britishmuseum.org/research/collection_online/collection_object_details.aspx?o bjectId $=418260 \&$ partId $=1 \&$ page $=2 \&$ searchText $=$ Sarapis $>$.

Na figura 3, que destoa das duas primeiras por ser uma representação zoomórfica, temos uma imagem fragmentada do touro Ápis, talvez uma oferenda votiva ou um busto, acompanhado do disco solar - uma representação comum na arte egípcia e a qual exercia uma função protetora - representado por Hélio entre os chifres. Serápis/Ápis está associado aos atributos solares do deus Hélio, tanto como os de Rê. Podemos pensar os atributos solares dessa divindade como também associadas ao contexto ctônico, uma vez que a barca solar navega pelo Duat e nela dá-se uma fusão com Osíris.

Podemos observar não uma simples apropriação da cultura estrangeira, mas a criação de um novo objeto que combina em si elementos egípcios e gregos, resultando no emaranhamento material. Apenas uma pequena parte da cabeça sobreviveu ao que provavelmente foi um busto completo do touro Ápis. Muito pouco restou: apenas os 
chifres, uma sobrancelha e está quebrado o local em que a orelha direita estaria. Os chifres erguem-se do topo da cabeça, o chifre direito não tem a ponta, assim como o esquerdo, mas este está danificado na junção com a cabeça. O disco do sol é abraçado pelos chifres e carrega em sua superfície, em relevo, um busto de Hélio com uma coroa raiada.

Com efeito, três prováveis funções podem ser destacadas dessa cultura material: em primeiro lugar no papel de ex-votos, os quais podemos apresentar como uma manifestação material de um contrato fiel-divindade, por meio do qual o devoto pedia por benesses, cura de moléstias, prosperidade das colheitas e, caso fosse atendido, ofertava em um templo um pequeno artefato como agradecimento. Essas peças também podiam ser encontradas no contexto do culto doméstico (residências) e funerário (tumbas), não se restringindo aos santuários.

Em seguida, temos as peças de terracota exercendo sua influência no contexto do lar. Nas residências a construção de nichos em paredes para a inserção de pequenas estatuetas e oferendas era uma prática comum. As peças nessa função cumprem o papel de protetoras do espaço doméstico, afastando forças negativas, atendendo preces, zelando pela saúde e bem-estar de todos os moradores. Esses artefatos também cumpriam o dever de propiciar a abundância e a riqueza, além de estabelecerem um meio de diálogo entre o devoto e a divindade.

Por fim, há a função exercida pelas peças dentro do contexto funerário. Ao levarse em consideração os principais atributos presentes em Serápis, tais como o emaranhamento dos deuses Osíris-Ápis e Dioniso - todos ligados à fertilidade e ressurreição -, ou ainda o calathos e a cornucópia - símbolos de abundância que não permitem ao morto sentir fome no além - percebe-se que as estatuetas e os ex-votos provavelmente possuíam seu papel ligado à vida após a morte, na qual agiam como guias e guardiãs do morto. Outro objeto presente na representação de Serápis, porém mais raro, é o caduceu de Hermes. Nesse caso, Serápis aparece como um condutor do morto, atributo ctônico exercido igualmente por Hermes que, no Egito, era associado a Thot, mas também a Anúbis no contexto funerário.

\section{Conclusão}

Neste artigo propusemos apresentar e discutir o culto de Serápis no Egito grecoromano e como esse deus intimamente ligado à ascensão da dinastia dos Ptolomeus alcançou aceitação, em um primeiro momento, entre a população de origem helena e, 
Mare Nostrum, ano 2021, v. 12, n. 1 .

posteriormente disseminou-se pelo Império Romano como um deus ligado à prosperidade, cura de moléstias e guardião funerário.

Os artefatos de terracota de Serápis são uma rica fonte para se ter acesso às práticas religiosas de várias camadas da população, com ênfase, nesta pesquisa, para as pessoas que não integravam a elite política nem a econômica. Focamos na forma como elas se relacionavam com o sagrado e como a cultura material influenciava o seu quotidiano, com seus papéis de ex-votos, estatuetas protetoras do lar e guardiãs da tumba e da vida após a morte.

Serápis aparece associado a Ísis e Harpócrates, formando a tríade de Alexandria, mas deuses como Hélio, Deméter e Hermanúbis também são representados ao seu lado. Com isso, podemos inferir que os atributos ctônicos e solares têm um destaque no culto de Serápis (vide gráfico 3). Apesar de sua popularidade o culto de Serápis não parece não ter se destacado tanto quanto o de Ísis, uma vez que esse último representa mais de $80 \%$ na proporção de peças Ísis-Serápis (vide gráfico 1).

Outro aspecto sobre o qual esta pesquisa se debruçou refere-se à hipótese dessa cultura material ser emaranhada (Stockhammer, 2012). Serápis pode manifestar esse emaranhamento da maneira "primordial" proposta por Stockhammer, ou seja, materialmente, com a manifestação física do deus sendo o resultado "novo" da combinação entre as entidades grega e egípcia. Em algumas peças do corpus documental, Serápis está representado segundo uma estética helena (chíton, himation, cabelo e barba volumosos e encaracolados) e portando a coroa atef.

Entretanto, em outras, a representação física não engloba nenhum traço do emaranhamento material greco-egípcio, porém o deus manifesta seu emaranhamento fora das fronteiras da materialidade, uma vez que ele em si é resultado do emaranhamento de vários deuses gregos e egípcios, tais como Osíris-Ápis, Hades, Dioniso e Hélio, apropriando, combinando e ressignificando seus diversos atributos e funções.

A ausência ou simples ignorância do método científico para escavações acabou por destruir a possibilidade de efetiva interpretação de todas as peças desta pesquisa. Nenhuma tem o contexto em que foi encontrada e metade do material não tem sequer a identificação da cidade ou região em que foi encontrada. Acrescentando isso ao fato de não terem sobrado muitos fragmentos da cultura material ligada ao culto popular de Serápis, é difícil tecer afirmações ou hipóteses com o mínimo de segurança. Contudo, o pouco que ainda nos resta é um testemunho valioso para a análise do emaranhamento 
Danillo Melo da Fonseca. Religião Popular no Egito Greco-Romano.

cultural e uma janela para tentarmos entender as densas relações entre egípcios, gregos e romanos em múltiplas esferas, sejam elas religiosa, econômica ou social.

Recebido: $29 / 08 / 2020$

Aprovado: $21 / 09 / 2020$ 


\section{REFERÊNCIAS BIBLIOGRÁFICAS}

\section{Fontes}

British museum. (2020, 16 de agosto). Collection online. London. Recuperado de: $<$ https://www.britishmuseum.org/collection>.

Dunand, F. (1990). Catalogue des terres cuites gréco-romaines d'Égypte. Musée du Louvre. Paris: Réunion des musées nationaux.

Dunand, F. (1979). Religion populaire en Égypte romaine. Les terres cuites isiaques du Musée du Caire. Leiden: E. J. Brill.

Plutarque. (1988). Oeuvres morales. Tome V. $2^{\mathrm{a}}$ partie. Isis et Osiris. Trad. Christian Froidefond. Paris: Les Belles Lettres.

Plutarque. (1995). Obras morales y de costumbres (Moralia). VI. Isis y Osiris. Diálogos Píticos. Trad. Francisca Pordomingo Pardo e José Antonio Fernández Delgado. Madrid: Gredos. (Biblioteca Clásica Gredos).

\section{Obras}

Alston, R. (1995). Soldier and society in Roman Egypt. A Social History. London/New York: Routledge.

Alston. (2002). The city in roman and byzantine Egypt. London and New York: Routledge.

Bastos, M. T. (2016). Análise e distribuição espacial de lucernas romanas de disco: o caso das províncias da Palestina e do norte da África. (Tese de Doutorado). Universidade de São Paulo, São Paulo, Brasil.

Bowman, A. K. (1989). Egypt after the Pharaohs 332 B.C.-A. 642: from Alexander to the Arab Conquest. Los Angeles: University of California Press.

Brancaglion, A. (2003). Manual de arte e arqueologia do Egito Antigo. Rio de Janeiro, RJ: Sociedade dos Amigos do Museu Nacional.

Brancaglion, A. (2004). Manual de arte e arqueologia do Egito Antigo II. Rio de Janeiro, RJ: Sociedade dos Amigos do Museu Nacional.

Burkert, W. (1993). Religião grega na época Clássica e Arcaica. Lisboa: Fundação Calouste Gulbenkian.

Capponi, L. (2011). Roman Egypt. London: Bristol Classical Press, 2011. 
Castro, E. J., Jr. (2019). Espaço funerário em Alexandria: tumba principal de Kom elShoqafa, séculos I e II d.C. (Dissertação de Mestrado). Universidade Federal do Rio Grande do Norte, Natal, Brasil.

Cunha, L. T. P. (2016). O sagrado na Roma imperial do séc. II d.C.: construção especial e ritualística do culto isíaco na obra O Asno de Ouro (Dissertação de Mestrado). Universidade Federal do Rio Grande do Norte, Natal, Brasil.

Donadoni, S. (Dir.). (1990). O homem egípcio. Lisboa: Editorial Presença.

Duarte, C.A. (2010). Estudo sobre a iconografia de Ápis durante o período farâ̂nico. (Tese de Doutorado). Universidade de São Paulo, São Paulo, Brasil.

Dunand, F. \& Zivie-Coche, Ch. (1991). Dieux et hommes en Égypte - 3000 av. J.-C.-395 apr. J.-C.. Paris: Armand Colin.

Frankfurter, D. (1998). Religion in roman Egypt. Assimilation and Resistance. Princeton: Princeton University Press.

Gama-Rolland, C. A. O contato com os deuses: as práticas mágico-religiosas no Egito Antigo. (2017) In C. K. B. Dias, S. C. Silva, \& C. E. C. Campos (Org.), Experiências religiosas no mundo antigo (pp. 49-65). Curitiba, PR: Prismas.

Leão, D. F. (2012). A globalização no Mundo Antigo: do polites ao kosmopolites. Coimbra: Imprensa da Universidade de Coimbra.

Manning, J. G. (2019). The ptolemaic governmental branches and role of temples and elite groups. In K. Vandorpe (Ed.), A companion to greco-roman Egypt and Late Antique Egypt (pp. 103-118). Hoboken, NJ : John Wiley \& Sons, Inc.

Moyer, I. S. (2011). Egypt and the limits of hellenism. New York: Cambridge University Press.

Naether, F. (2019). New deities new habits. In K. Vandorpe (Ed.), A companion to grecoroman Egypt and Late Antique Egypt (pp. 439-448). Hoboken, NJ : John Wiley \& Sons, Inc.

Neiva, C. O. (2017). O Poder legitimador de Serápis em disputa na época Antonina (96192): um estudo comparado entre a iconografia monetária alexandrina e os Acta Alexandrinorum (Dissertação de Mestrado). Universidade Federal do Rio de Janeiro, Rio de Janeiro, Brasil.

Sales, J. C. (2007). O culto de Serápis e a coexistência heleno-egípcia na Alexandria ptolomaica. Revista lusófona de ciências das religiões. (12), 309-322.

Sandri, S. Terracottas. (2012). In C. Riggs (Ed.), The Oxford handbook of roman Egypt (pp. 630-647). Oxford: Oxford University Press.

Shafer, B. E. (Org.). (2002). As religiões no Egito Antigo. Deuses, mitos e rituais domésticos. Trans. Luís S. Krausz. São Paulo, SP: Nova Alexandria. 
Mare Nostrum, ano 2021, v. 12, n. 1.

Stockhammer, Ph. (Ed.). (2012). Conceptualizing Cultural Hybridization: a transdisciplinary approach. Heldelberg: Springer.

Vasques, M. S. (2000). A religião isíaca no Egito greco-romano: as estatuetas de terracota (Dissertação de Mestrado). Universidade de São Paulo, São Paulo, Brasil.

Vasques. (2005). Crenças funerárias e identidade cultural no Egito romano: máscaras de múmia. (Tese de Doutorado). Universidade de São Paulo, São Paulo, Brasil. 


\section{Popular Religion in Greco-Roman Egypt The Cult of Serapis.}

\section{ABSTRACT}

Serapis was a god created by the first pharaoh of the Lagid dynasty (305-30 B.C.), Ptolemy I Soter as a guardian god of the new sovereigns and of the city of Alexandria. The iconographic representation of Serapis followed the pattern of the Greek deities, but it was also the result of a properly Egyptian element in the composition of its name. In this article, we analyze de religious practices and popular religion associated with the god by the investigation of the material culture made of terracotta from the Greco-Roman Egypt. Furthermore, we sustain the hypothesis that Serapis is the result of the contact and entanglement of the Egyptian and Greek religions, the result of an environment marked by miscegenation and close cultural contact.

\section{KEYWORDS}

Greco-roman Egypt; cultural entanglement; popular religion; Serapis; terracotta. 